\title{
KOMUNITAS MAKROZOOBENTOS DI KAWASAN PENAMBANGAN PASIR DI SUNGAI PROGO (Macrozoobenthos Community in Sand Mining Area of Progo River)
}

\author{
Auladina Syafiya dan Suwarno Hadisusanto* \\ Fakultas Biologi, Universitas Gadjah Mada, Sekip Utara, Yogyakarta, 55281. \\ *Penulis korespondensi. Tel: 08562937358. Email: suwarnohs@ugm.ac.id.
}

Diterima: 30 Oktober 2018

Disetujui: 26 Desember 2018

\begin{abstract}
Abstrak
Sungai memiliki peranan penting bagi manusia dan makhluk hidup lainnya, di antaranya adalah sebagai habitat bagi komunitas makrozoobentos dan pemanfaatan material berupa pasir dan batu sebagai bahan bangunan. Sungai Progo merupakan salah satu sungai yang hampir di sepanjang sungainya terdapat aktivitas penambangan pasir. Jika aktivitas ini dilakukan terus menerus dalam jumlah banyak dan tanpa pengawasan yang baik dapat menyebabkan terjadinya erosi dan degradasi serta sedimentasi pada bagian-bagian tertentu sungai. Maka dari itu dilakukan penelitian ini untuk mempelajari pengaruh aktivitas penambangan pasir terhadap distribusi dan kemelimpahan komunitas makrozoobentos di Sungai Progo, serta Functional Feeding Group (FFG) yang paling melimpah dan parameter fisikokimia yang memengaruhinya. Penelitian ini dilakukan dalam tiga tahap, yaitu mencuplik dan preparasi sampel makrozoobentos, identifikasi sampel, dan pengukuran parameter fisiko-kimia. Aktivitas penambangan pasir di Sungai Progo berpengaruh secara tidak langsung terhadap makrozoobentos, yaitu dengan menyebabkan adanya erosi dan degradasi di kawasan penambangan pasir serta sedimentasi di bagian hilir. FFG makrozoobentos di Sungai Progo yang paling melimpah adalah tipe scraper dan collector. Berdasarkan analisis regresi dan korelasi Pearson didapatkan hasil bahwa fosfat berkorelasi positif terhadap densitas makrozoobentos di bagian hulu Sungai Progo, intensitas cahaya berkorelasi positif terhadap densitas makrozoobentos di bagian tengah Sungai Progo, dan kecepatan arus berkorelasi positif terhadap densitas makrozoobentos di bagian hilir Sungai Progo.
\end{abstract}

Kata kunci: komunitas makrozoobentos, penambangan pasir, Sungai Progo, sungai.

\begin{abstract}
River has an important role for human and other organisms, among them are as habitat of macrozoobenthos community and the utilization of the material, such as river sand and gravel for building material. Progo River is one of rivers which have sand mining activities almost all along the river. If this activity being done continuously, in a big amount and without a good supervision, it could lead to erosion, degradation and sedimentation in some specific parts. Therefore, this research has an aim to study the effects of sand mining activity towards the distribution and the abundance of macrozoobenthos community in Progo River, and also to study which Functional Feeding Group (FFG) is the most abundant and the physic-chimic parameter that affecting them. This research was conducted in three steps, sampling and preparation of macrozoobenthos's sample, sample's identification, and the measurement physicochemical parameter. Sand mining activity in Progo River effect indirectly towards macrozoobenthos by causing erosion and degradation in sand mining area as well as sedimentation in downstream. The most abundant FFG of macrozobenthos in sand mining area of Progo River are scraper and collector. Based on regression and Pearson correlation analysis the results show that phosphate correlated positively against the density of macrozoobenthos in the headwaters of Progo River, light intensity correlated positively against the density of macrozoobenthos in the midstream of the Progo River, and current velocity correlated positively against the density of macrozoobenthos in the downstream of the Progo River.
\end{abstract}

Keywords: macrozoobenthos community, sand mining, Progo River, river.

\section{PENDAHULUAN}

Sungai memiliki peranan penting bagi manusia dan makhluk hidup lainnya. Manfaat dari sungai diantaranya yaitu sebagai habitat bagi komunitas makrozoobentos. Selain itu, material sungai berupa pasir dan batu juga biasa dimanfaatkan sebagai bahan bangunan dan lainnya.

Sungai Progo merupakan salah satu sungai yang masih banyak dimanfaatkan material sungainya sampai sekarang. Material yang ada di Sungai Progo sebagian berasal dari lahar dingin Gunung Merapi yang terbawa arus lalu kemudian mengendap. Oleh karena itu, terdapat banyak aktivitas penambangan pasir di sepanjang Sungai Progo. Kegiatan penambangan pasir ini dapat mengurangi timbunan material yang berasal dari lahar dingin. Namun, jika hal ini dilakukan terus menerus dalam jumlah banyak dan tanpa pengawasan yang baik dapat menyebabkan 
terjadinya erosi dan degradasi. Selain itu, pada sungai bagian hilir dapat terjadi penumpukan material pasir di pinggir ataupun di dasar sungai. Jika hal ini dibiarkan, maka dapat memengaruhi kualitas perairan pada sungai tersebut (Ikhsan dkk, 2015).

Metode pemantauan kualitas air dapat dilakukan dengan menggunakan indikator biologis. Metode ini disebut biomonitoring, yang merupakan suatu petunjuk biologis, baik menggunakan hewan ataupun tumbuhan, untuk menunjukkan kondisi lingkungan berdasarkan keberadaan dan jumlah makhluk hidup. Umumnya bioindikator yang digunakan berupa makrozoobentos yang hidup di dasar perairan. Makrozoobentos dapat digunakan untuk mengukur kualitas perairan karena hidupnya yang relatif menetap, tidak bermigrasi meskipun ada perubahan kondisi lingkungan, mudah diambil, dan sensitif terhadap polusi organik maupun anorganik (Hendarti, 2007; Magfirah dkk, 2014).

Selain menggunakan komponen biologi, kualitas perairan juga dapat diidentifikasi dengan menggunakan komponen fisik maupun kimiawi dari suatu perairan. Parameter fisiko-kimia tersebut dapat berupa kadar oksigen terlarut (DO), alkalinitas, $\mathrm{pH}$, temperatur, kecepatan arus, serta kandungan nitrat dan fosfat (Magfirah dkk, 2014).

Berdasarkan uraian tersebut, pengawasan dan pengendalian terhadap aktivitas penambangan pasir di Sungai Progo perlu dilakukan. Salah satunya yaitu dengan meneliti dampak dari aktivitas penambangan pasir di Sungai Progo terhadap distribusi dan kemelimpahan komunitas makrozoobentos pada tiga wilayah sungai, yaitu hulu, tengah, dan hilir.

\section{METODE PENELITIAN}

\section{Waktu dan Lokasi}

Penelitian dilakukan di tiga bagian Sugai Progo, yaitu hulu, tengah, dan hilir (Gambar 1) dan dilakukan pada tanggal 17 April 2018. Titik sampling bagian hulu letaknya di Kali Krasak, Kecamatan Ngluwar, Kabupaten Magelang, Jawa Tengah. Titik sampling bagian tengah letaknya di bawah Jembatan Ngapak/Kebon Agung I, Kecamatan Nanggulan, Kabupaten Kulon Progo, DI Yogyakarta. Titik sampling bagian hilir terletak di Kecamatan Pajangan, Kabupaten Bantul, DI Yogyakarta.

Pada tepi sungai bagian hulu terdapat vegetasi riparian yang masih rimbun dengan vegetasi dominan berupa pohon, serta tumbuhan lain yaitu bambu, rumput, dan semak. Substrat yang dominan di sungai bagian hulu adalah pasir dan kerikil. Pada bagian tengah terdapat aktivitas penambangan pasir. Sungai memiliki karakteristik berkelok dengan lebar \pm 8 meter. Pada tepi sungai bagian tengah terdapat vegetasi yang masih rimbun dengan vegetasi dominan berupa pohon dan semak. Substrat yang dominan di sungai bagian tengah adalah pasir dan lumpur. Pada sungai bagian hilir juga terdapat aktivitas penambangan pasir. Lebar sungai \pm 10 meter dengan vegetasi pada tepi sungai dominan rumput. Substrat yang dominan pada bagian hilir adalah kerikil dan batu. Hampir tidak ada pasir atau sedimen untuk dicuplik.

\section{Bahan dan Alat}

Alat yang digunakan dalam penelitian ini adalah Petersen dredge untuk menyuplik sampel, botol gelap, botol sampel, termometer, $\mathrm{pH}$ meter, lux meter, erlenmeyer, gelas beker, metlin, bola pingpong, stopwatch, kertas label, alat tulis, saringan bertingkat, mikroskop, lup, pinset, dan buku identifikasi. Bahan yang digunakan dalam penelitian ini yaitu formalin dan alkohol 70\% untuk mengawetkan bentos, alkalinitas kit, DO kit, dan $\mathrm{CO}_{2}$ kit.

\section{Prosedur}

Penelitian dilakukan di tiga bagian sungai, yaitu di bagian hulu, tengah, dan hilir. Pada masing-masing bagian ditentukan satu titik sampling dan Pada masing-masing bagian ditentukan satu titik sampling dan sampel dicuplik sebanyak lima kali ulangan. Sampel sedimen dicuplik sebanyak $\pm 500 \mathrm{~g}$ dengan menggunakan Petersen dredge 1L.

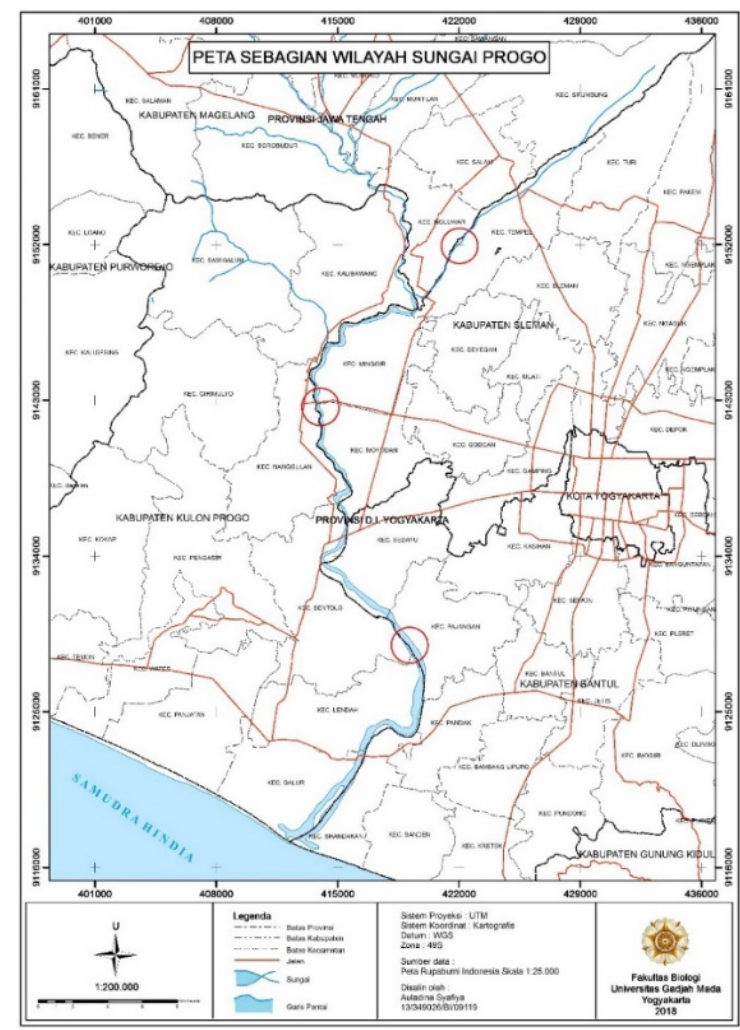

Gambar 1. Peta lokasi pengumpulan data. 
Cuplikan sampel kemudian diberi formalin dan selanjutnya disaring menggunakan saringan bertingkat. Sampel yang telah disaring kemudian dikoleksi dalam botol sampel dan diberikan alkohol $70 \%$ untuk diamati. Sampel makrozoobentos yang telah dikoleksi kemudian diamati dengan mikroskop dan diidentifikasi dengan menggunakan buku identifikasi dan digolongkan berdasarkan functional feeding group.

Pada tiap ulangan dilakukan pengumpulan data parameter fisika-kimia, yaitu kadar oksigen terlarut dalam air (DO), kadar $\mathrm{CO}_{2}$, alkalinitas, temperatur udara dan air, $\mathrm{pH}$ air, jeluk, intensitas cahaya, dan kecepatan arus. Sampel air dianalisis biochemical oxygen demand (BOD) (mg/L), nitrat (mg/L) dan total fosfat (mg/L). Data yang telah diperoleh kemudian dianalisis dalam bentuk frekuensi, frekuensi relatif, densitas, densitas relatif, nilai penting, dan indeks diversitas Shannon-Wiener serta indeks dominansi Simpson.

\section{HASIL DAN PEMBAHASAN}

Berdasarkan penelitian yang telah dilakukan pada tanggal 17 April 2018, terdapat 24 jenis makrozoobentos yang ditemukan di bagian hulu, tengah, dan hilir Sungai Progo. Data yang dihasilkan dari hasil analisis ditampilkan dalam bentuk histogram, tabel, dan grafik.

\section{Densitas dan Kemelimpahan Makrozoobentos di Sungai Progo}

Gambar 2 menunjukkan bahwa densitas di bagian hulu Sungai Progo yang tertinggi adalah spesies Sulcospira testudinaria yang yaitu sebanyak 12 individu $/ \mathrm{m}^{2}$. Pada bagian tengah densitas makrozoobentos tertinggi yaitu anggota subfamilia Chironominae sebanyak 2,2 individu/ $\mathrm{m}^{2}$. Densitas makrozoobentos tertinggi di bagian hilir adalah anggota subfamilia Chironominae yaitu 5,4 individu $/ \mathrm{m}^{2}$.

Berdasarkan Gambar 2, dapat diketahui bahwa Sulcospira testudinaria yang memiliki densitas tertinggi pada bagian hulu tidak ditemukan di bagian tengah tetapi ditemukan sedikit di bagian hilir. Sulcospira testudinaria biasa ditemukan di perairan dengan arus cepat seperti sungai yang berbatu (Marwoto and Isnaningsih, 2012). Hal ini sesuai dengan kondisi sungai di bagian hulu yang berbatu dan berarus kuat, sehingga spesies ini memiliki densitas tertinggi di bagian hulu. Sedangkan pada bagian hilir, arus sungai lebih tenang sehingga spesies ini memiliki densitas lebih sedikit dibandingkan pada bagian hulu.

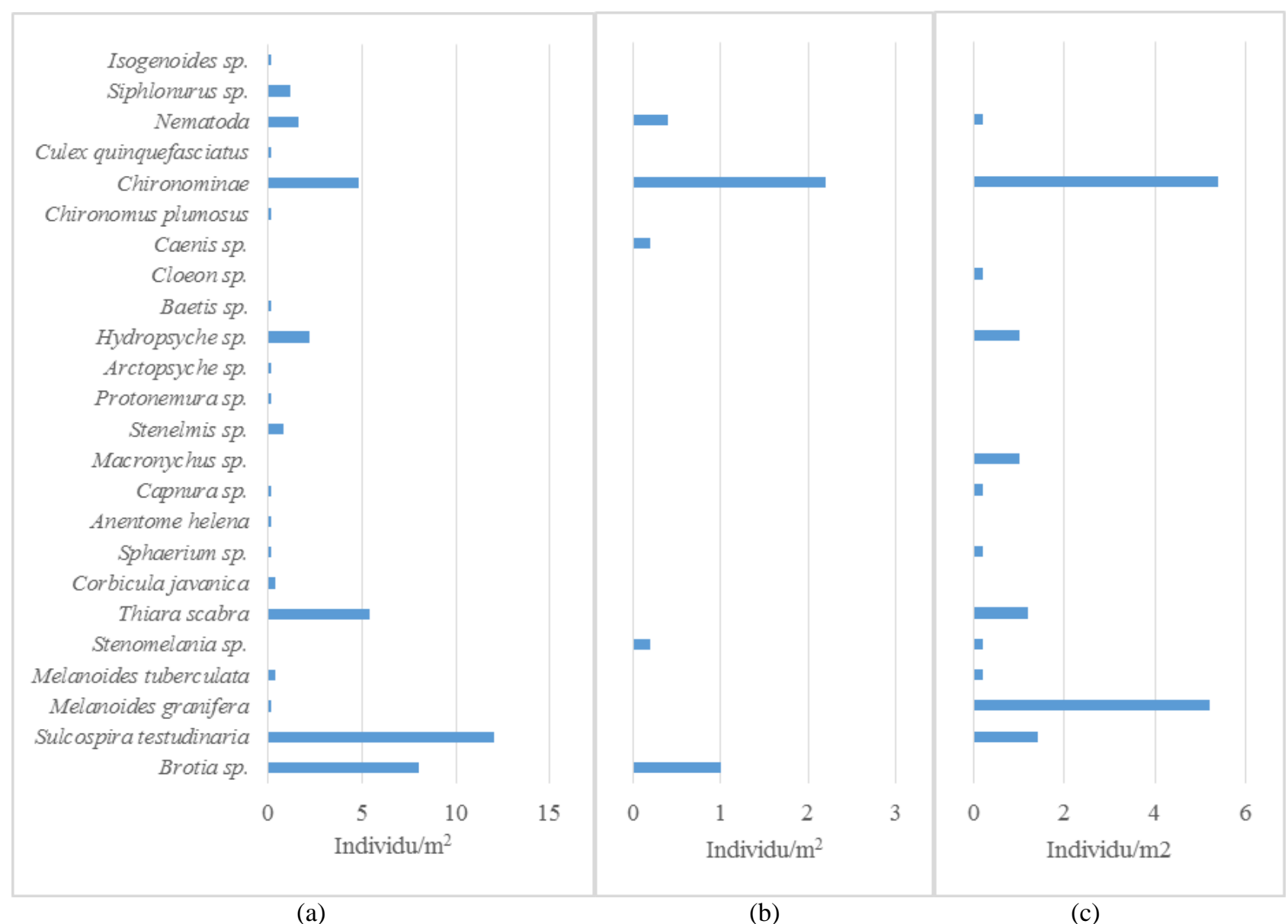

Gambar 2. Densitas makrozoobentos di Sungai Progo bagian (a) hulu (b) tengah dan (c) hilir 
Anggota subfamilia Chironominae yang memiliki densitas tertinggi pada bagian tengah dan hilir serta ditemukan juga di bagian hulu. Chironominae adalah anggota dari familia Chironomidae. Chironomidae terdistribusi secara meluas dan merupakan salah satu anggota dari kelas insekta yang ditemukan dalam jumlah yang melimpah di perairan tawar. Anggota familia ini memiliki toleransi yang luas terhadap kondisi lingkungan di sekitarnya (Pinder, 1986). Dengan demikian anggota subfamilia Chironominae ini memiliki densitas yang tinggi di bagian tengah dan hilir, serta memiliki densitas yang cukup tinggi di bagian hulu.

Dari Gambar 2 juga dapat diketahui bahwa densitas makrozoobentos di bagian hulu merupakan densitas yang paling banyak diantara ketiga bagian sungai. Pada bagian hulu masih belum ada aktivitas penambangan pasir, sedangkan pada bagian tengah dan hilir terdapat banyak aktivitas penambangan pasir di sepanjang sungai. Banyaknya aktivitas penambangan pasir tersebut dapat mengganggu habitat serta dapat memengaruhi komunitas makrozoobentos yang ada pada kawasan penambangan pasir tersebut.
Gambar 3 menunjukkan bahwa frekuensi makrozoobentos yang tertinggi di bagian hulu yaitu spesies Brotia sp. Frekuensi makrozoobentos tertinggi di bagian tengah yaitu Nematoda dan anggota subfamilia Chironominae. Frekuensi makrozoobentos tertinggi di sungai bagian hilir yaitu anggota subfamilia Chironominae. Frekuensi merupakan gambaran terhadap kemampuan suatu spesies untuk dapat hadir di setiap ulangan. Nilai frekuensi yang tinggi menunjukkan bahwa suatu spesies memiliki adaptasi yang baik pada tiap ulangan titik sampling.

Brotia sp. merupakan spesies yang eurytrophic, yaitu spesies yang memiliki adaptasi meluas terhadap adanya perubahan lingkungan. Namun, pada umumnya spesies ini hidup di perairan yang mengalir dan bersih (Rabett, 2012). Hal ini dapat menunjukkan bahwa spesies ini memiliki kemampuan adaptasi yang baik pada bagian sungai ini. Selain itu, dapat diketahui juga bahwa air di sungai bagian hulu masih bersih sehingga masih banyak makrozoobentos yang dapat hadir.

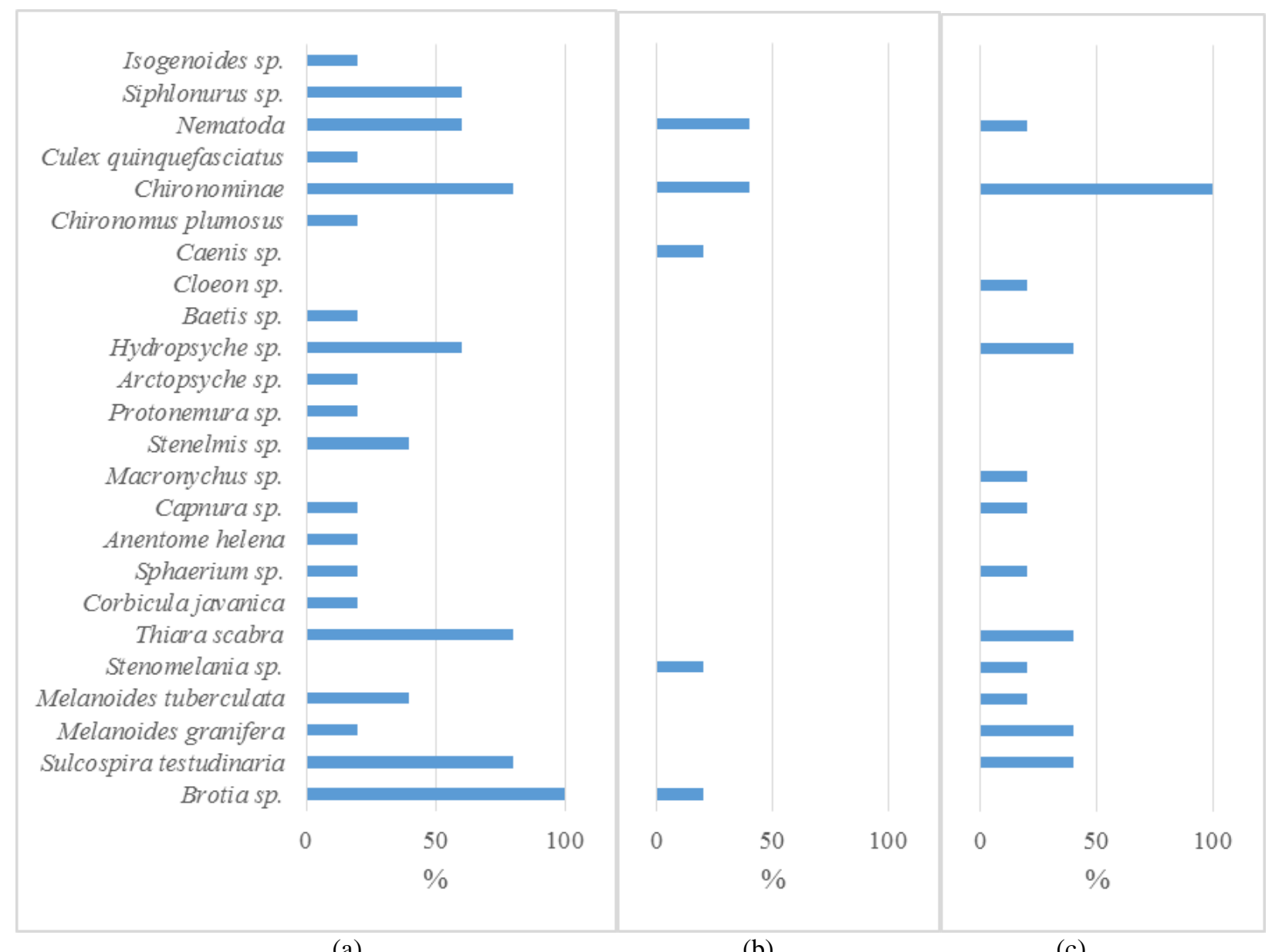

(a)

(b)

(c)

Gambar 3. Frekuensi makrozoobentos di Sungai Progo bagian (a) hulu (b) tengah dan (c) hilir. 
Pada bagian tengah, Nematoda dan anggota subfamilia Chironominae hadir di dua ulangan dan makrozoobentos lainnya hanya hadir di satu ulangan. Nematoda pada umumnya dapat ditemukan di dasar sungai yang berupa batuan, lumpur, ataupun pasir. Nematoda dapat hidup di lingkungan yang terdapat polusi yang ekstrem atau dalam kondisi yang stress. Nematoda tidak langsung berpindah dari kondisi lingkungan yang kurang mendukung (Zullini, 1988). Hal ini diperkirakan yang menyebabkan Nematoda memiliki frekuensi tertinggi pada bagian utara dari titik sampling ini meskipun terdapat banyak aktivitas penambangan pasir di dekat titik sampling. Aktivitas penambangan ini dapat mengurangi kuantitas sedimen pada dasar sungai dan dapat menyebabkan adanya lubang-lubang sisa penambangan. Terganggunya habitat makrozoobentos ini menyebabkan tingkat kehadiran makrozoobentos menjadi rendah.

Anggota subfamilia Chironominae dapat hadir di setiap ulangan sehingga dapat diketahui makrozoobentos ini memiliki adaptasi yang sangat baik pada bagian sungai ini atau memiliki toleransi yang lebih luas dibandingkan dengan jenis makrozoobentos lainnya yang ada di bagian sungai ini.

Dengan berdasarkan Gambar 3, juga dapat diketahui bahwa tingkat kehadiran spesies paling tinggi adalah di bagian hulu, kemudian di bagian hilir, dan paling rendah di bagian tengah. Hal ini menunjukkan bahwa bagian hulu sungai memiliki kondisi lingkungan yang mendukung kehidupan makrozoobentos. Rendahnya frekuensi pada bagian tengah dan frekuensi cukup rendah di bagian hilir diperkirakan disebabkan oleh adanya perubahan pada lingkungan di sekitarnya, seperti adanya aktivitas penambangan pasir. Aktivitas penambangan pasir ini dapat menyebabkan makrozoobentos juga ikut terangkut sehingga dapat memengaruhi tingkat kehadiran suatu spesies pada lingkungan tersebut.

Gambar 4 menunjukkan bahwa spesies yang memiliki nilai penting tertinggi di bagian hulu adalah S. testudinaria yaitu sebesar 40,68\%. Spesies yang memiliki nilai penting tertinggi di bagian tengah adalah anggota subfamilia Chironominae yaitu sebesar $83,57 \%$. Spesies yang memiliki nilai penting tertinggi di bagian hilir adalah anggota subfamilia Chironominae yaitu sebesar $57,93 \%$.

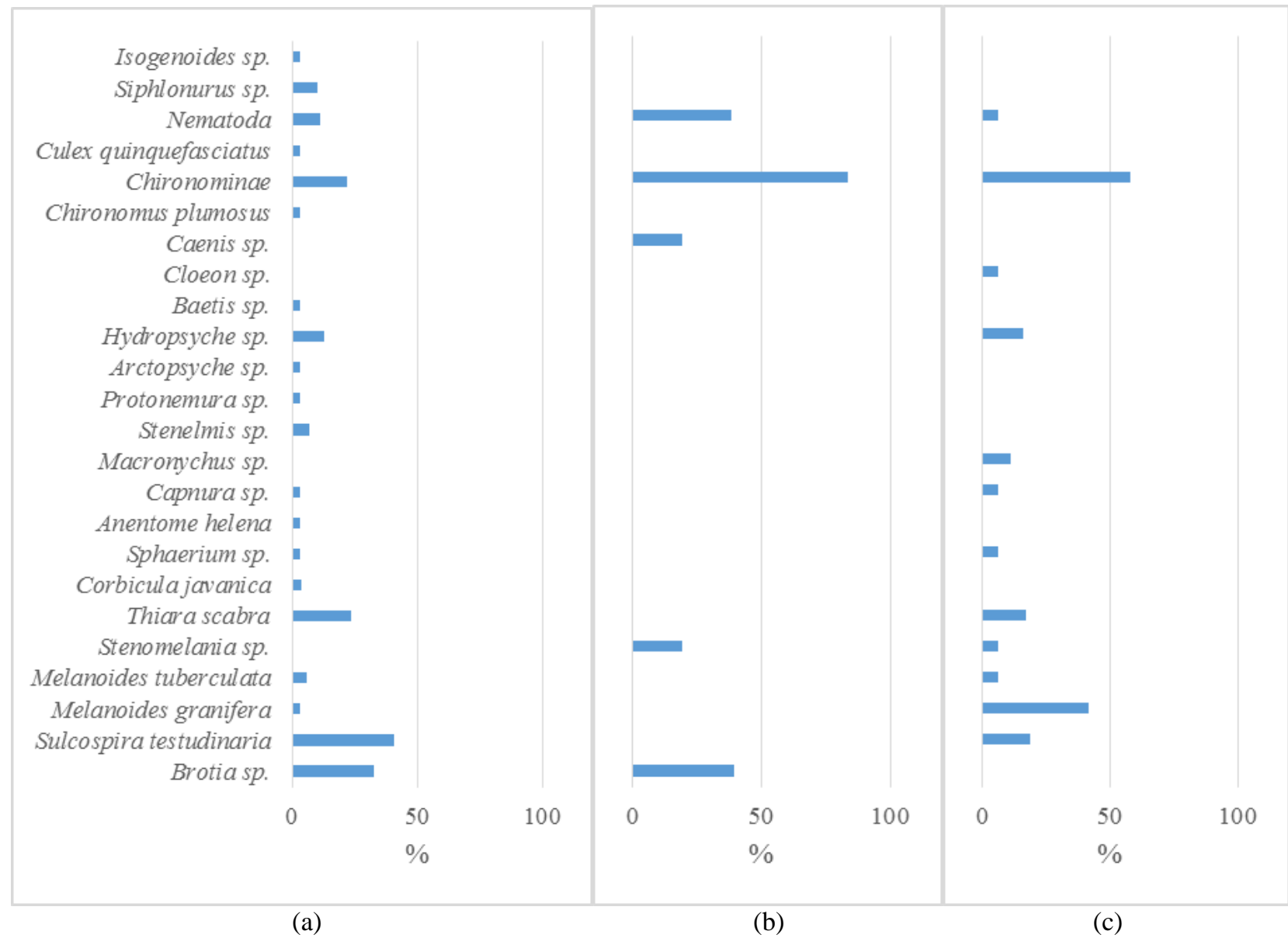

Gambar 4. Nilai penting makrozoobentos di Sungai Progo bagian (a) hulu (b) tengah dan (c) hilir. 
Nilai penting merupakan akumulasi dari densitas relatif dan frekuensi relatif. Nilai penting menunjukkan suatu spesies memiliki peran penting dalam stabilitas ekosistem. Hal ini berarti $S$. testudinaria memiliki peran penting dalam ekositem di bagian hulu sungai. Spesies ini memiliki habitat di sungai atau danau yang berarus tenang maupun deras (Isnaningsih dan Listiawan, 2010). Spesies ini hidupnya bergantung pada tingkat oksigen yang tinggi di perairan sekitarnya sehingga membuatnya termasuk dalam kategori sensitive terhadap polusi (Kelly dkk, 2017). Berdasarkan hal tersebut, spesies ini dapat menunjukkan bahwa kualitas perairan pada bagian sungai ini masih baik. Berdasarkan Gambar 4. dapat diketahui juga bahwa anggota subfamilia Chironominae memiliki peran penting dalam ekositem di bagian tengah dan hilir Sungai Progo.

Gambar 5. menunjukkan bahwa jika semua makrozoobentos di tiga bagian sungai digabungkan, didapatkan nilai penting tertinggi yaitu anggota subfamilia Chironominae dengan nilai sebesar 37,36\%. Hal ini berarti bahwa anggota subfamilia Chironominae memiliki peran penting dalam ekositem di Sungai Progo.
Chironominae merupakan subfamilia dari Chironomidae. Familia Chironomidae merupakan anggota dari ordo Diptera. Anggota dari ordo Diptera termasuk dalam kategori tolerant, yaitu mampu bertahan hidup di kondisi yang buruk atau terdapat tekanan. Anggota ordo ini dapat bertahan hidup dalam kondisi tanpa oksigen selama beberapa jam (Pinder, 1986). Anggota ordo ini juga memiliki kemampuan untuk membentuk koloni dan reproduksi tinggi (Muntalif dkk, 2016).

Tabel 1. menunjukkan bahwa pada bagian hulu, indeks diversitas Shannon-Wiener sebesar 2,069. Pada bagian tengah, indeks diversitas Shannon-Wiener sebesar 1,205. Pada bagian hilir, indeks diversitas Shannon-Wiener sebesar 1,795.

Tabel 1. Indeks diversitas makrozoobentos di Sungai Progo.

\begin{tabular}{llll}
\hline No & Titik Sampling & H' & D \\
\hline 1 & Hulu & 2,069 & 0,180 \\
2 & Tengah & 1,205 & 0,380 \\
3 & Hilir & 1,795 & 0,230 \\
\hline
\end{tabular}

Keterangan: H’= Indeks Diversitas Shannon-Wiener. D = Indeks Dominansi Simpson.

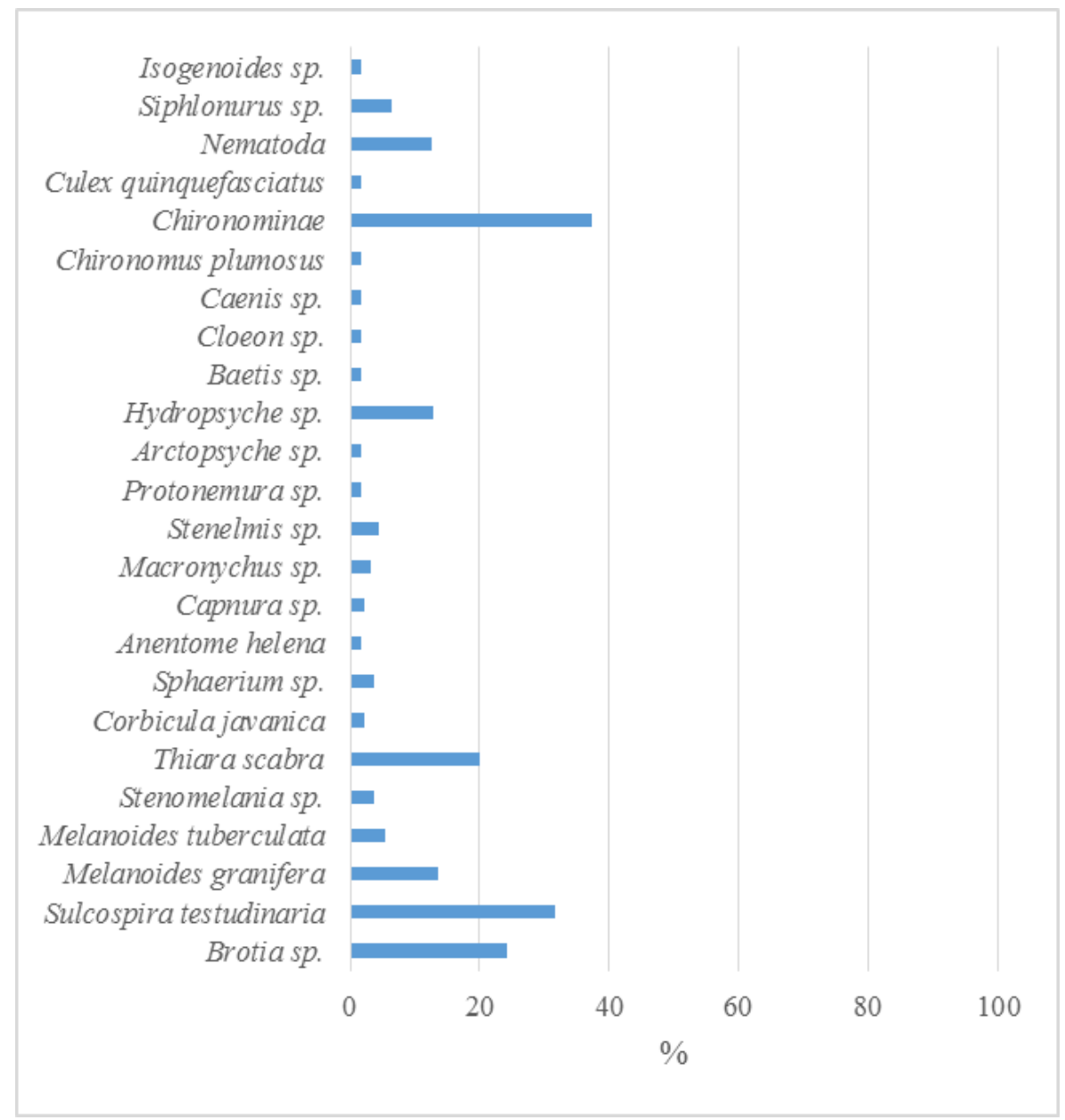

Gambar 5. Nilai penting makrozoobentos di Sungai Progo. 
Indeks diversitas menunjukkan seberapa besar keanekaragaman spesies penyusun komunitas makrozoobentos di Sungai Progo. Berdasarkan hasil tersebut didapatkan indeks diversitas Shannon-Wiener dengan nilai antara 1 dan 3 pada ketiga titik sampling yang menunjukkan tingkat keanekaragaman sedang. Indeks diversitas Shannon-Wiener pada titik sampling hulu paling tinggi, kemudian hilir dan tengah. Ini menunjukkan bahwa tingkat keanekaragaman tertinggi ada pada titik sampling bagian hulu, kemudian hilir dan tengah. Hal tersebut juga dapat memberikan gambaran bahwa ketiga bagian sungai masih dalam kondisi yang cukup baik. Indeks dominansi Simpson di ketiga titik sampling lebih mendekati nilai 0 yang menunjukkan bahwa tidak adanya kelimpahan atau ketidaksamarataan.

Berdasarkan analisis statistik menggunakan uji ANOVA (analysis of variance) dengan membandingkan densitas makrozoobentos di tiga titik sampling, yaitu Sungai Progo bagian hulu, tengah, dan hilir dapat diketahui bahwa terdapat beda nyata antara ketiga titik sampling. Selanjutnya dilakukan uji least significant difference (LSD) untuk mengetahui secara spesifik perbedaan antar ketiga titik sampling tersebut.

Hasil uji LSD menunjukkan bahwa terdapat perbedaan yang signifikan antara titik sampling sungai bagian hulu dan tengah, serta antara titik sampling bagian hulu dan hilir, sedangkan antara titik sampling bagian tengah dan hilir tidak terdapat perbedaan yang signifikan. Berdasarkan hasil tersebut, dapat diketahui bahwa di titik sampling bagian hulu memiliki kemelimpahan makrozoobentos paling tinggi, kemudian di bagian hilir, dan tengah.

\section{Komposisi Functional Feeding Group (FFG) Makrozoobentos di Sungai Progo}

Gambar 6. menunjukkan bahwa pada bagian hulu sungai, makrozoobentos didominasi oleh FFG tipe scraper sebesar 67,53\%. Hal ini kurang sesuai dengan river continuum concept (RCC) yang menjelaskan bahwa di bagian hulu sungai didominasi oleh FFG tipe collector, lalu shredder, dan paling sedikit predator dan scraper. FFG yang dominan di bagian hulu adalah scraper yang anggotanya didominasi oleh Gastropoda. Diperkirakan terdapat sumber makanan untuk scraper yang lebih banyak dibandingkan sumber makanan untuk collector pada bagian sungai ini, sehingga lebih banyak ditemukan makrozoobentos tipe scraper dibandingkan dengan tipe collector. Selain itu, Gastropoda juga merupakan bentos yang termasuk dalam kategori tolerant, sehingga dapat ditemukan dalam jumlah yang cukup banyak di bagian sungai ini.

Gambar 8. menunjukkan bahwa pada bagian hilir, FFG yang mendominasi adalah tipe scraper sebesar 50\%, kemudian collector sebesar 42,68\%. Hal ini kurang sesuai dengan RRC yang menjelaskan bahwa di sungai bagian hilir didominasi oleh FFG tipe collector lalu predator. Pada bagian sungai ini, FFG dominan adalah scraper yang anggotanya didominasi oleh gastropoda. Gastropoda merupakan bentos yang termasuk dalam kategori tolerant, sehingga dapat ditemukan dalam jumlah yang cukup banyak di bagian sungai ini.
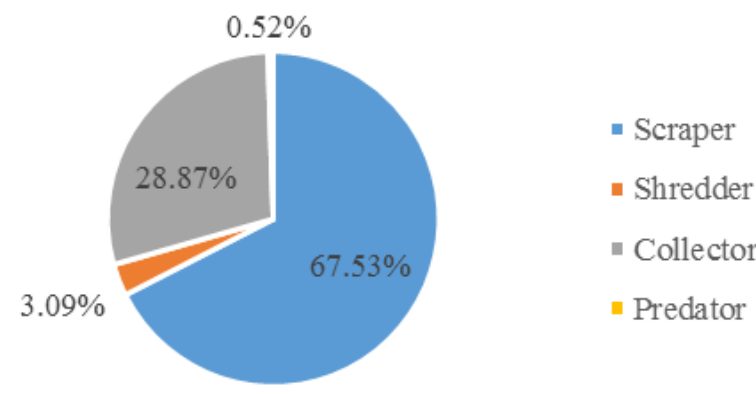

Gambar 6. Komposisi functional feeding group (FFG) di Sungai Progo bagian hulu.

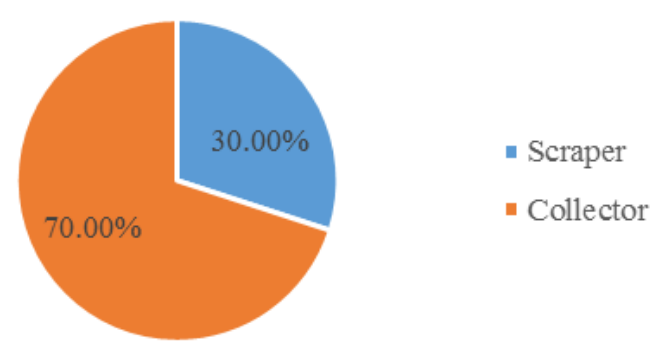

Gambar 7. Komposisi functional feeding group (FFG) di Sungai Progo bagian tengah.

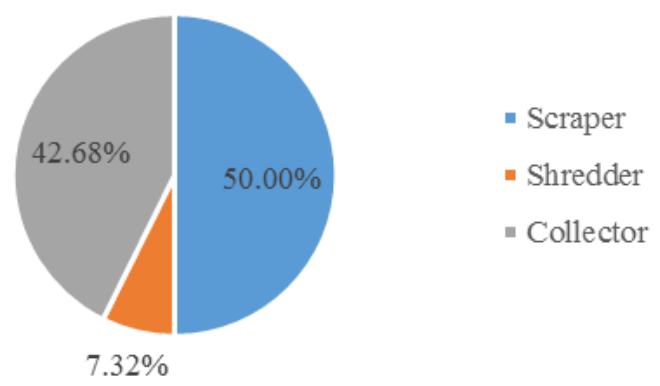

Gambar 8. Komposisi functional feeding group (FFG) di Sungai Progo bagian hilir. 


\section{Korelasi Parameter Fisiko-kimia terhadap Densitas Makrozoobentos di Sungai Progo}

Korelasi antara parameter fisiko-kimia dengan densitas makrozoobentos dapat menunjukkan pengaruh parameter tersebut terhadap densitas. Analisis korelasi yang ditampilkan merupakan gambaran dari analisis data menggunakan analisis regresi linier.

Pemilihan parameter fosfat sebagai faktor yang dikorelasikan dengan densitas adalah karena berdasarkan hasil analisis regresi yakni nilai $\mathrm{R}^{2}$ merupakan nilai yang paling tinggi dari faktor lain, yaitu sebesar 0,2659 yang berarti pengaruhnya terhadap densitas adalah sebesar 26,59\%. Gambar 9 menunjukkan adanya korelasi positif antara fosfat dan densitas yang berarti meningkatnya fosfat akan meningkat pula densitas makrozoobentos. Namun, tiap jenis makrozoobentos memiliki respon yang berbeda terhadap fosfat. Jumlah fosfat yang terlalu tinggi dan melewati batas baku mutu air dapat memengaruhi kualitas air sehingga keberadaan makrozoobentos juga dapat terpengaruh.

Pemilihan parameter intensitas cahaya sebagai faktor yang dikorelasikan dengan densitas adalah karena berdasarkan hasil analisis regresi yakni nilai $\mathrm{R}^{2}$ merupakan nilai yang paling tinggi dari faktor lain, yaitu sebesar 0,578 yang berarti pengaruhnya terhadap densitas adalah sebesar 57,8\%. Gambar 10 menunjukkan adanya korelasi positif antara intensitas cahaya dan densitas yang berarti meningkatnya intensitas cahaya akan meningkat pula densitas makrozoobentos. Intensitas cahaya yang tinggi dapat meningkatkan proses fotosintesis tumbuhan air. Tumbuhan air merupakan salah satu sumber makanan bagi makrozoobentos, sehingga semakin meningkatnya intesitas cahaya dapat meningkatkan densitas makrozoobentos.

Pemilihan parameter kecepatan arus sebagai faktor yang dikorelasikan dengan densitas adalah karena berdasarkan hasil analisis regresi yakni nilai $\mathrm{R}^{2}$ merupakan nilai yang paling tinggi dari faktor lain, yaitu sebesar 0,6829 yang berarti pengaruhnya terhadap densitas adalah sebesar 68,29\%. Gambar 11 menunjukkan adanya korelasi positif antara kecepatan arus dan densitas yang berarti meningkatnya kecepatan arus akan meningkat juga densitas makrozoobentos. Arus yang kuat dapat menyebabkan terjadinya turbulensi. Adanya turbulensi ini dapat meningkatkan persebaran sumber makanan bagi makrozoobentos sehingga secara tidak langsung dapat memengaruhi distribusi makrozoobentos (Waples dkk, 2017).

\section{Parameter Fisiko-kimia Sungai Progo}

Gambar 12 menunjukkan adanya fluktuasi secara spasial pada parameter-parameter tersebut. Kisaran parameter $\mathrm{pH}$ antara ketiga bagian sungai tidak ada perbedaan yang siginifikan, kecuali pada bagian hilir terdapat $\mathrm{pH}$ bernilai 7 atau lebih rendah dari $\mathrm{pH}$ di bagian hulu dan tengah. Alkalinitas merupakan kemampuan perairan dalam menetralisir asam, yang berarti alkalinitas berperan dalam sistem buffer perairan. Hal ini berarti adanya peningkatan $\mathrm{pH}$ akan menurunkan alkalinitas. Gambar 12. menunjukkan adanya peningkatan alkalinitas di bagian hilir karena $\mathrm{pH}$ air turun ke arah netral/asam. Kisaran $\mathrm{pH}$ di tiga titik sampling masih dalam Standar Batas Baku Mutu Air Peraturan Gubernur DIY No. 20 Th. 2008 tentang Baku Mutu Air di Provinsi DIY (Kelas II), yaitu antara 6-9.

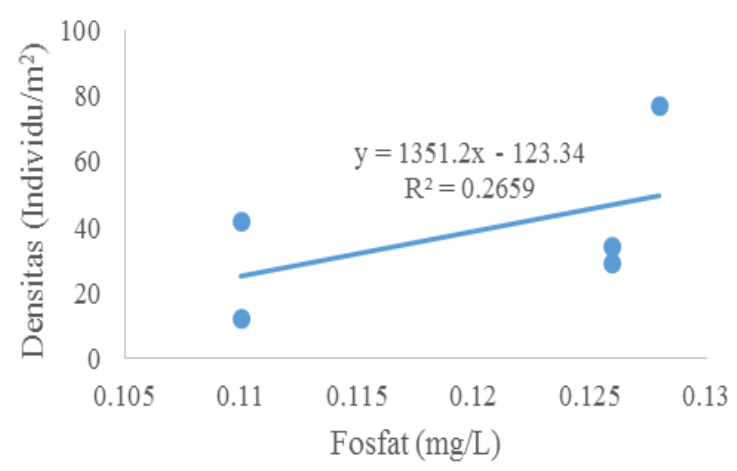

Gambar 9. Korelasi antara fosfat dan densitas makrozoobentos Sungai Progo bagian hulu.

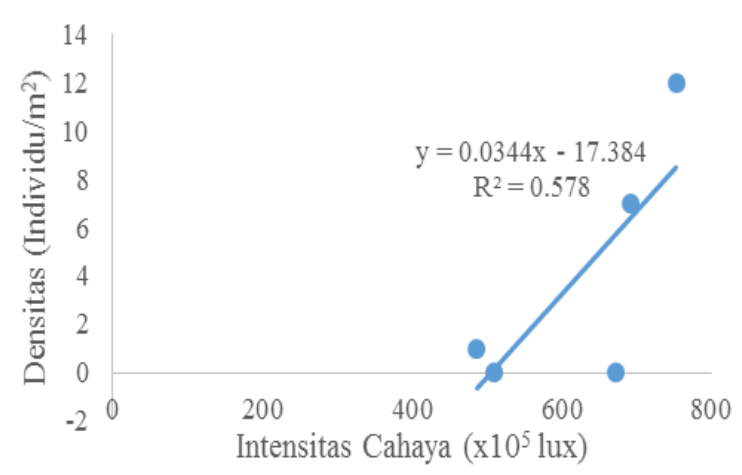

Gambar 10. Korelasi antara intensitas cahaya dan densitas makrozoobentos Sungai Progo bagian tengah.

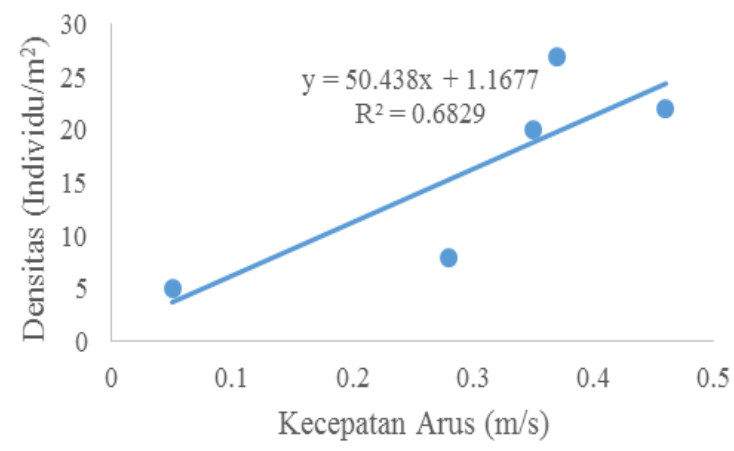

Gambar 11. Korelasi antara kecepatan arus dan densitas makrozoobentos Sungai Progo bagian hilir. 


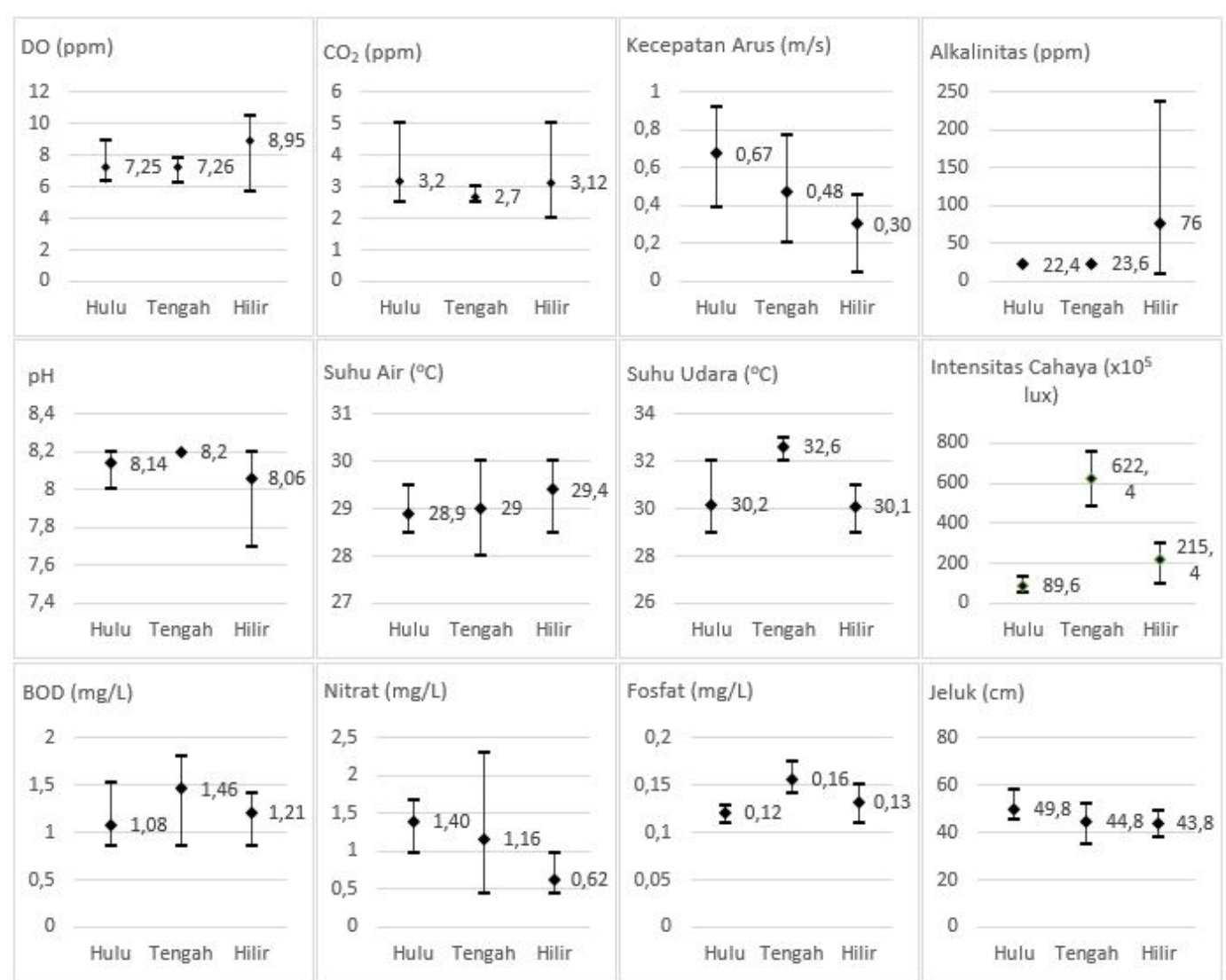

Gambar 12. Parameter fisiko-kimia pada air Sungai Progo.

Kadar oksigen terlarut (DO) dan $\mathrm{CO}_{2}$ bebas dalam perairan dapat dipengaruhi oleh kecepatan arus. Turbulensi arus dapat menyebabkan adanya gelembung-gelembung udara yang dapat meningkatkan kadar oksigen terlarut dalam perairan. Sebaliknya, arus akan melarutkan karbon ke dalam perairan. Gambar 12 menunjukkan nilai Biochemical Oxygen Demand (BOD) tertinggi ada pada titik sampling tengah, kemudian hilir, lalu hulu. BOD menunjukkan kadar oksigen yang dibutuhkan oleh organisme perairan untuk menguraikan bahan organik. Batas maksimum BOD yang diperbolehkan sesuai Standar Baku Mutu Air Peraturan Gubernur DIY No. 20 Th. 2008 tentang Baku Mutu Air di Provinsi DIY (Kelas II) adalah $3 \mathrm{mg} / \mathrm{L}$. Nilai BOD pada ketiga titik sampling masih dalam kisaran baku mutu air yang diperbolehkan.

Gambar 12 menunjukkan bahwa intensitas cahaya pada bagian tengah dan hilir jauh lebih tinggi dari di bagian hulu karena pada bagian hulu badan sungai dinaungi oleh vegetasi di samping sungai. Sedangkan pada bagian tengah dan hilir badan sungai terpapar matahari secara langsung. Jeluk terdalam ada pada bagian hulu, tengah, lalu hilir. Jeluk yang dalam dapat menyebabkan sinar matahari dapat masuk lebih dalam juga sehingga mendukung proses fotosintesis bagi organisme air, satu diantaranya fitoplankton. Fitoplankton merupakan salah satu sumber makanan bagi bentos sehingga secara tidak langsung dapat memengaruhi densitas bentos.

Gambar 12 juga menunjukkan kisaran nitrat tertinggi ada pada bagian tengah, lalu hulu dan terendah di hilir, sedangkan total fosfat tidak terdapat perbedaan yang signifikan. Nitrat dapat masuk ke perairan lewat limbah domestik dan industri atau air buangan dari lahan pertanian ataupun peternakan. Senyawa fosfat dapat masuk ke perairan lewat limbah rumah tangga, pertanian, peternakan, perikanan, dan industri. Fosfat juga dapat ditemukan di perairan sebagai sumber alami. Batas nitrat yang diperbolehkan berdasarkan Standar Baku Mutu Air Peraturan Gubernur DIY No. 20 Th. 2008 tentang Baku Mutu Air di Provinsi DIY (Kelas II) adalah $10 \mathrm{mg} / \mathrm{L}$ dan total fosfat adalah $0,2 \mathrm{mg} / \mathrm{L}$. Nitrat dan total fosfat di tiga titik sampling masih dalam kisaran tersebut.

\section{KESIMPULAN}

Aktivitas penambangan pasir berpengaruh secara tidak langsung terhadap makrozoobentos, yaitu dengan mempengaruhi substrat dan adanya sisa-sisa aktivitas penambangan pasir di Sungai Progo. Functional feeding group (FFG) makrozobentos di Sungai Progo yang paling melimpah adalah tipe scraper. Berdasarkan analisis 
regresi dan korelasi Pearson didapatkan hasil bahwa fosfat, intensitas cahaya, dan kecepatan arus paling berpengaruh terhadap densitas makrozoobentos di masing-masing titik sampling. Fosfat berkorelasi positif terhadap densitas di Sungai Progo bagian hulu. Intensitas cahaya berkorelasi positif terhadap densitas di Sungai Progo bagian tengah. Kecepatan arus berkorelasi positif terhadap densitas di Sungai Progo bagian hilir.

\section{DAFTAR PUSTAKA}

Callisto, M., and Graça, M.A.S., 2013. The Quality and Availability of Fine Particulate Organic Matter for Collector Species in Headwater Streams. International Review of Hydrobiology, 98(3):132-140.

Hendarti, L.M., 2007. Menepis Kabut Halimun: Rangkaian Bunga Rampai Pengelolaan Sumberdaya Alam. Yayasan Obor Indonesia. Jakarta.

Ikhsan, J., Pratama, R.B., dan Harsanto, P., 2015. Kajian Kegiatan Penambangan Pasir dan Dampaknya terhadap Dasar Sungai di Kali Progo Hilir Pasca Letusan Merapi tahun 2010. Sumber Daya Air, 9:291-296.

Isnaningsih, N.R., dan Listiawan, D.A., 2010. Keong dan Kerang dari Sungai-sungai di Kawasan Karst Gunung Kidul. Zoo Indonesia, 20(1):1-10.

Kelly, C., Mitrasetia, T., and Sugardjito, J., 2017. An Assessment of A Tropical Urban Stream
Using Benthic Macroinvertebrates as A Bioindicator in Muara Angke, Jakarta, Indonesia. Bonorowo Wetlands, 7(2):65-73.

Magfirah, Emiryati, dan Haya, L.O.M.Y., 2014. Karakteristik Sedimen dan Hubungannya dengan Struktur Komunitas Makrozoobentos di Sungai Tahi Ite Kecamatan Rarowatu Kabupaten Bombana Sulawesi Tenggara. Jurnal Mina Laut Indonesia, 14(4):117-131.

Marwoto, R.M., dan Isnaningsih, N.R., 2012. The Freshwater Snail Genus Sulcospira Troschel, 1857 from Java, with Description of A New Species from Tasikmalaya, West Java, Indonesia (Mollusca: Gastropoda: Pachychilidae). The Raffles Bulletin of Zoology, 60(1):1-10.

Muntalif, B.S., Chasanah, N., dan Faza. M.F., 2016. Relationship Population Density of Aquatic Sediment Macrozoobenthos to River Water Quality Parameters: Case Study of Upstream Citarum River in Bandung Regency. Journal of Environmental Science and Engineering, 5:117-125.

Pinder, L.C.V., 1986. Biology of Freshwater Chironomidae. Annual Review of Entomology. 31:1-23.

Rabett, R.J., 2012. Human Adaptation in the Asian Paleolithic. Cambridge University Press. Cambridge.

Waples, J.T., Bootsma, H.A., and Klump, J.V., 2017. How Are Coastal Benthos Fed. Limnology and Oceaongraphy, 2:18-28. 